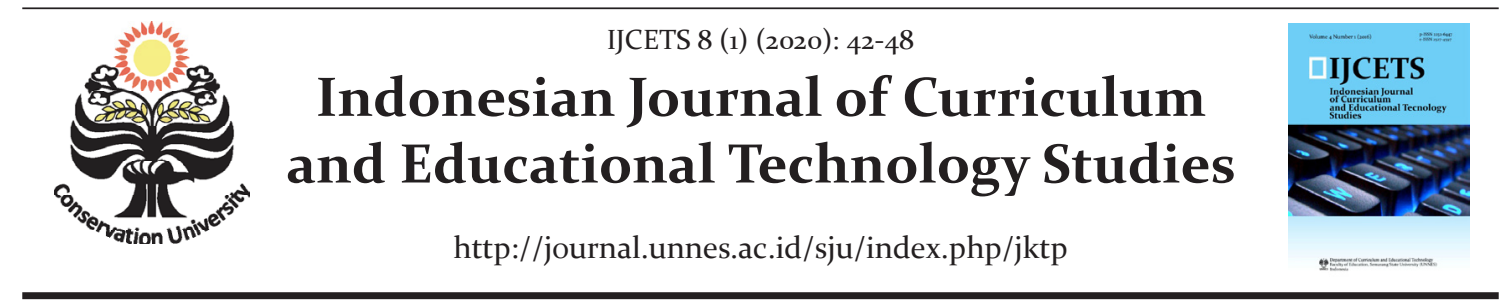

\title{
Problem-Based Learning Model for Junior High School in Indonesia (2010-2019)
}

\author{
Binti Zakkiyatul Faqiroh ${ }^{\text {}}$ \\ ${ }^{1}$ Faculty of Education, Universitas Negeri Malang, Malang, Indonesia \\ DOI: https://doi.org/10.15294/ijcets.v8i1.38264
}

\section{Article History}

Received : April 2020 Accepted : April 2020 Published : April 2020

\section{Keywords}

Cognitive ability; learning model; problem-based learning

\begin{abstract}
Abstrak
Problem-based learning atau pembelajaran berbasis masalah adalah model pembelajaran yang lebih mengedepankan pemecahan masalah untuk dapat mengetahui perkembangan kemampuan berpikir peserta didik dan menjadikan pembelajaran lebih bermakna. Perlu diketahui bahwasnya ada beberapa permasalahan yang terjadi di dalam pembelajaran yaitu masih banyaknya guru yang menggunakan model pembelajaran konvensional yang membuat siswa sering merasa bosan dan tidak nyaman dalam mengikuti pembelajaran. Tujuan penelitian ini adalah untuk mengetahui perkembangan pembelajaran dengan menggunakan model pembelajaran problem-based learning oleh para siswa pada jenjang sekolah menengah pertama di Indonesia pada tahun 2010-2019. Metode yang digunakan adalah metode kualitatif. Hasil yang akan diperoleh adalah model pembelajaran problem-based learning memang banyak digunakan dan lebih diminati oleh siswa sekolah menengah pertama pada tahun 2010-2019. Penelitian ini menggunakan pendekatan kualitatif dan hasilnya menunjukkan bahwa penggunaannya memang banyak pada periode tahun-tahun tersebut dan dikehendaki oleh siswa untuk meningkatkan kompetensi mereka. Oleh karena itu para guru perlu mengembangkan inovasi-inovasi baru problem-based learning ini.
\end{abstract}

\begin{abstract}
Problem-based learning model is a learning model emphasizes on solving the problem as a mean to know the students' thinking skills and bring learning process more meaningful. But there are some problems in the learning that many teachers still relied their learning practices conventionally in which make students often bored and uncomfortable within the classroom. The purpose of this research is revealing the development of learning practices using problem-based learning model of junior high school students in Indonesia in 2010-2019. This research used qualitative approach and the result shown that problem-based learning model has been used widely and has attracted many first high school students to improve their competencies. Therefore, teachers need to create such innovations based on problembased learning.
\end{abstract}

Corresponding author :

Address: : Jl. Semarang No.5, Faculty of Education,

Universitas Negeri Malang, Malang, Indonesia, 65145

E-mail: binti.zakkiyatul.1801216@students.um.ac.id
(C) 2020 Universitas Negeri Semarang p-ISSN 2252-6447 e-ISSN 2527-4597 


\section{INTRODUCTION}

The rapid development era of today has made every individual inevitably have to keep up with the endless progress of the era. It makes everyone must continuously hone his or her ability to face life in the future, hence the establishment of one of the avenues for the individual to be able to hone his or her ability for future life. The definition of education is a fundamental thing that every individual must do to hone his or her skills. With the education of each individual's talents or interests can be developed very well to give some contribution to the society (Fristadi \& Bharata, 2015).

Education in the $21^{\text {st }}$-century aims to develop cognitive abilities of students, in this article context, especially junior high school students whose aim is to make junior high school students solve problems that will be faced in the surrounding environment. Establishing the students' cognitive abilities needs a lengthy process. It can be done by mastering technology, accustomed to carrying out cooperatively, and also encourage collaboration between friends to easily solve the problems they face (Insyasiska et al., 2017).

On the other hand, education also participates in forming human resources to develop science and technology. Education also has the potential to nurture student ways of thinking critically, creatively, systematically and the character of each student is obtained and developed. This comes from teachers who can patiently produce quality human resources in the future (Simbolon \& Tapilouw, 2015).

The success of a teacher in producing quality human resources, of course, uses strategies or models in the learning process. Learning strategies or models have a considerable influence on the success of a student in the educational environment. Especially, to develop cognitive abilities which of course requires a learning model that directly related to the development of student cognitive abilities, and it was problembased learning model that has many potentials for that purposes.

Problem-based learning is a learning model who has potential to connect many problems in everyday life, including student everyday life. From this point, in a very specific context, the junior high school students indirectly could hone their critical, creative, and systematic thinking to achieve the core competencies on each subject taught by teachers. Problem-based learning model can develop students creative abilities and problem solving (Wartono et al., 2018).

Problem-based learning model also appropriate to be applied in all subjects, because this learning model will enforce the students to be more active in developing their critical thinking skills, creative, systematic and problem solving, and all of these skills related to their learning outcomes (Fristadi \& Bharata, 2015). Given the current official national curriculum, student activities are highly demanded by the teacher. In the current 2013 curriculum, a teacher only acting as a facilitator, of course he/she does not forget to oversee the learning process and improvement of each student.

On the other hand, the succeed obtained by teachers in developing cognitive abilities of junior high school students certainly has many obstacles and problems. These problems include the learning process that often encounter educators explaining the subject for using conventional or traditional learning models such as using lecture methods, which is clear that the conventional model now is no longer appro-priate because it will tend to student boredom and a lack of student interest on understanding the lesson. It has also been clearly stated in the current 2013 curriculum that learning process must be more controlled by students (student-centered) than teacher centered, which one help students explore their cognitive abilities, especially in terms of problem solving. The educators only act as facilitator in the learning process.

Another problem when asked with the problem-based learning model is that there are still students who rely on information from the teacher, because the teacher is still considered as the main source of information, where it will cause boredom and students are less comfortable following the ongoing learning process. Most students when learning only by memorizing the subject matter do not understand, analyze, or even solve problems that may often be encountered in everyday life. This is what makes students lack good cognitive abilities. The results also have an impact on learning outcomes while in class.

\section{METHOD}

The methods used in this research is literary study approach (Shankar, 2010). This study was conducted by looking at trends or problems 
that exist in the learning process, especially on the learning model used, where the problem has an impact on the cognitive abilities of junior high school students in Indone-sia in 2010-2019. Thus, this research will provide an understanding or solution for teachers to change the learning model that previously used conventional methods into problem-based learning model, which when use it clearly it could bring a very positive impact on students' cognitive abilities in Indonesia.

\section{RESULT AND DISCUSSION}

In this results and discussion section I examine the problem-based learning model, i.e. its fixed definition, its advantages and disadvantages, its clumps of sciences in Indonesia year 2010-2019, the impact of problem-based learning model in junior high school in Indonesia year 2010-2019, and the development chart of problem-based learning model in Indonesia year 2010-2019.

\section{A. Definition of Problem-based Learning Model}

Any succeed achieved by someone certainly has the way or strategy they use so they can succeed as expected. Moreover, they are successful because their cognitive abilities are extraordinary, or perhaps because of the ability to resolve problems encountered before they succeed or succeed can be resolved properly. In education teachers can be said to have succeeded in producing young people who can think critically, creatively, and systematically because the learning models they use really help students develop these abilities. As has been mentioned early, one of the influential methods according to this issue is problem-based learning method that can be traced to the thoughts of John Dewey. This learning model is reflected in several studies conducted by John Dewey that discuss the learning process through memorable learning or not. According to John Dewey learningbased experienced that inspired problem-based learning has indirect interaction between stimulus and response as well as the interaction between learning process and the environment (Saleh, 2013).

In the beginning initial the rise of problem-based learning was not really accepted by the wider learning community officially, so many efforts have been done to propose it for the wider community. For instance, the innovative development has been conducted by the Faculty of Medicine of McMaster University, Canada. The problem-based learning model was initially introduced in medical school at Mc Master, Canada in 1960, and now has been used as a learning method in many medical schools in Indonesia even around the world (Mansur et al., 2012). Since this very early development of the method, now problem-based learning method become one of the most famous and important method in this industrial revolution 4.0 era and has been used widely in law, economics, architecture, engineering, and school curriculum studies.

Based on the brief illustration previously, it can be taken into the definition that problembased learning model intended to address the students' daily problems as the focus of the study, and in this article it also has been used for junior high school students' context. The students' problems they encounter in everyday life create situations that could nurture their critical reasoning to solve it properly. Problem-based learning method develop such questions to encourage their critical reasoning, creativity, and systematic thinking skills to solve the problems they face. Therefore, problem-based learning model does not only useful and meaningful for students' academic achievement by understanding and mastering the core of the subjects properly, but also have several real potentials to solve the problems empirically (Kharida et al., 2009).

Thus, problem-based learning can be defined as an educational method used to enhance and encourage students' understanding master the subjects and overcome the existing problems they faced, moreover it also tend to produce such a scientific knowledge (Halarnkar et al., 2012). This model certainly has degree of advantages and disadvantages in its implementation, of course a teacher also needs to know the strengths and weaknesses of each learning model, including problem-based learning method in order to avoid the wrong and incorrect learning method according to its objective and characters of the subjects.

\section{B. Advantages and Disadvantages of the Problem-based Learning Model}

Moreover, according to the context of this article, problem-based learning model has 
advantages and disadvantages, Saleh (2013) said that (1) problem-based learning is a suitable model for junior high school students in their lessons related to problem solving skills, (2) problem-based learning can make students discover new things in their lives, (3) problem-based learning can increase students' activeness with-in the classroom, (4) problem-based learning can help students apply the academic knowledge to solve their everyday life problems, (5) problembased learning can improve students' cognitive abilities, i.e. critical thinking, creative, problem solving, and systematizing their thinking, and (6) problem-based learning could improve students' scientific competence (see also Duda et al., 2019).

Saleh (2013) also said that there are some teachers who face difficulties on giving students such problems, so that they cannot solve them easily and quickly. The success that will be gained by this learning takes a quite long time. He also found that there is lack of deep and proper understanding of the learning model by teachers and students. Therefore, problem-based learning model is not arbitrarily used in all subjects, sometimes teacher should move to be the center of the learning process. Furthermore, it will be hard for the teacher if he/she face a very diverse student within a classroom, especially on giving them such assignments.

\section{The coverage of Problem-based Learning}

According to several references, problembased learning has a wide range of coverage, not only in science subjects, especially natural science subjects, but also social sciences, literature, etc, because the main purposes of the model is to nurture students' critical thinking, creativity, and systematic reasoning through solving the problems. Of course, problems are not only in natural sciences. For instances, Nicholl and Lou (2012) who said that learning model was very helpful the educators in explaining the subject matter, including for junior high school students. Problem-based learning model in its implementation is widely implemented in groups, which one group is accompanied by one teacher, so it will be easier to evaluate and if it is done it will make the class more interesting and interactive (Nicholl \& Lou, 2012).

Furthermore, Ramadhani et al. (2019) said that problem-based learning model mainly used in science subjects and mathematics subjects whose goal is to improve creativity, critical thinking, and problem solving skills provided by educators. In addition, in several study problembased learning model already uses Google's LMS help (Learning Management System Google). Moreover, Halarnkar et al. (2012) also said that the implementation of problem-based learning also be found in health studies, one of them in Nepal country application of problem-based learning is to use problems that exist in hospital patients, for which this student gained knowledge about health sciences and can also improve problem solving ability.

So, problem-based learning model is not only for science, but also in health sciences. So not only science in school but also science elsewhere like hospitals also need to be understood (Halarnkar et al., 2012). Problem-based learning models are also found in the dentistry sciences that is used as a model to help broaden the understanding of the approach or strategy (Nadershahi et al., 2013). Furthermore, problem-based learning model also appropriate for development project to solve the problems (Svanström et al., 2012). Problem-based learning model has a positive impact on students by improving students' ability to apply their knowledge in clinical situations (Bassir et al., 2014).

\section{The Impact of Problem-based Learning Model in Junior High School in Indonesia Year 2010-2019}

Each learning model used to support and assist the learning process certainly has a very important impact on improving the ability of each student. Several researches below have degree of impact on the discourse of improving student academic achievement in Indonesia since 2010-2019, especially in junior high school student learning activities.

First, most of the impact of problem-based learning are on students' critical thinking skills in several subjects. Setyorini et al. (Setyorini et al., 2011) conducting such study and found that problem-based learning improve the students ' critical thinking in physical science subjects in the sub-subjects GLBB (Straight Lines Change Irregularly). Study conducted by Palinusa (2013) also concluded that problem-based learning models can improve students critical thinking skills in realistic mathematical subjects rather than conventional mathematics. Such example on study in 2015 also concluded that this model was able to improve students' critical thinking skills (Simbolon \& Tapilouw, 2015). 
Dharma et al. (2019) found that problembased learning model has a positive impact that the critical thinking skills of a group of students combined with cooperative learning model of STAD. In 2019 for instance there is such a research on the implementation of problem-based learning model that help students in critical thinking, moreover student also become more active within the classroom learning practices (Sunarti \& Fadilah, 2019).

Second, there are plethora of studies in mathematic used problem-based and most of them show the impact on students' improvement on their academic skills. For instance, problem-based learning in 2012 is capable of being a good model for modern mathematical communication than the ability of mathematical communication using conventional means (Fatimah, 2012). The problem-based learning model carries a positive impact to junior high school students, where a problem-based learning model can indirectly improve the ability of mathematical representation of students, than when students use conventional learning models (Surya et al., 2013). Problem-based learning models have significantly higher impact on algebraic material mathematical subjects rather than using conventional learning models (Ajai et al., 2013).

Moreover, problem-based learning model also improve students' mathematic creative critical thinking skills and self-esteem in mathematics in junior high school (Gunantara et al., 2014). Next, problem-based learning models also help junior high school students to improve their mathematical problem solving skills and increase their creativity, rather than when they use conventional learning models (Saragih \& Habeahan, 2014). Problem-based learning model improving students' literacy skills in mathematics in the triangular and quadrilateral material of class students VII in SMP Negeri 5 Pallangga Gowa Regency (Indah et al., 2016). Problembased learning assisted by PoWs in mathematics learning also has a positive and good influence on students' skills to solve such mathematics problems (Partini et al., 2017). Furthermore, problem-based learning model brings an effective impact on students' problems solving mathematically (Putri et al., 2013).

Third, problem-based learning also improves students' skills to accomplish their tasks and encourage their motivation to study. For instances, Nargundkar et al. (2014) according to their study said that problem-based learning model has a positive impact for junior high school students, which can motivate learning and improve students' performance on the semester's final exam with an average of 9o, it also im-prove student group assignment performance. Merit et al. (2017) also said that problem-based learning is an effective model used in the learning process, which can improve academic achievement of K-8 students' science, including knowledge retention, conceptual development, and attitude. Nurdyansah (2018) also proposed that problembased learning could improve students' ability to ask and answer, from low thinking (knowledge, understanding, and application) to think high level (analysis, synthesis, evaluation) (Nurdyansyah, 2018).

In other study problem-based learning also help students explore their argumentative abilities successfully (Si et al., 2019). Problembased learning models also have a significant influence on the problem-solving skills faced by students and can also bring a positive impact to the student learning environment. Problembased learning also facilitates the development of togetherness in classroom setting (Ferreira \& Trudel, 2012). Moreover, problem-based learning encouraged the students' achievement and they become more motivated to learn (Zaduqisti, 2010). Strengthening the previous statement, problem-based learning model also improve students' attitudes toward STEM learning approach (science, technology, engineering and mathematics) and career choice exploration in the future (Lou et al., 2011).

All these topics based on previous studies in the implementation of problem-based learning depict the major trend in such studies in Indonesian context. It means, much of the study on problem-based learning in Indonesia since 2010-2019 related to the contributions of the learning model toward students' creativity, critical thinking, problem solving skills, learning motivation, attitude, high order thinking skills, etc.

\section{E. The Development Chart of Problem- based Learning Model in Indonesia Year 2010-2019}

Based on the basic assumption that most of Indonesian scholars still laid their information search on Google, below is the brief illustration on the implementation of problem-based 


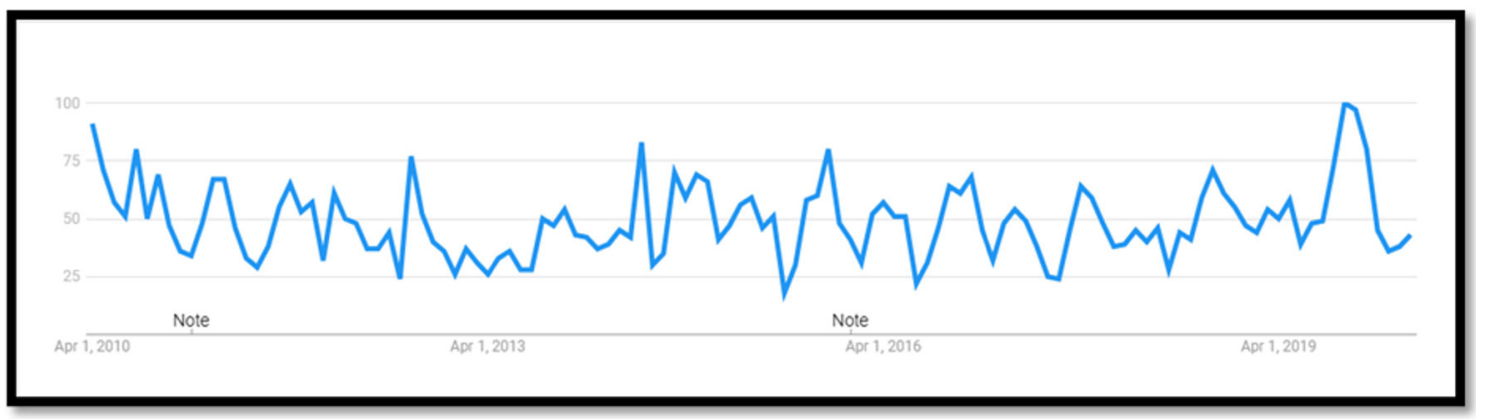

Picture 1 Brief Illustration in the Implementation of Problem-Based Learning Model in the Last Ten Years in Indonesia

learning model in Indonesian context since 2010-2019, all the data is obtained through Google search engine.

According to the illustration above, problem-based learning model in Google Trends shows that problem-based learning model has been used in the last 10 years in education in a wide and varied subjects and topics. For instances, in Biology, Physics, Mathematics, and Social Sciences subjects that very helpful for students understanding. This learning model also improve students' learning interest and comfortability as well as their academic achievement and outcomes, critical thinking skills, and solving the real problems they face in general. It seems that there is a constant interest on how using problem-based learning model in Indonesian context for the last 10 years since 2010-2019 by several scholars in junior high school context. Its wide using of the learning model prove that problem-based learning has been perceived as ap-propriate and compatible with the purposes of many subjects and the purpose of learning practices elsewhere for junior high school context.

\section{CONCLUSION}

Problem-based learning is an important learning model that mainly help the students to gain a better performance in several subject and skills, i.e. critical thinking, creativity, problem solving, innovation, thinking systematically, etc. It concluded that problem-based learning model has been perceived as highly compatible with many subjects and the purposes of learning practices more than the old-fashioned learning model such as giving a lecture in front of the class, particularly in junior high school context in Indonesia (2010-2019). The whole analysis in this article shows that problem-based learning model has a potential as a learning model for many learning contexts and purposes, because it tend to encourage the learning practices and students to solve the problems in which it is become one of the most important skills in the $21^{\text {st }}$ century (see i.e. Trilling \& Fadel, 2009).

\section{REFERENCES}

Ajai, J. T., Imoko, B. I., \& O’kwu, E. I. (2013). Comparison of the learning effectiveness of problembased learning (PBL) and conventional method of teaching algebra. Journal of Education and Practice, 4(1), 131-135.

Bassir, S. H., Sadr-Eshkevari, P., Amirikhorheh, S., \& Karimbux, N. Y. (2014). Problem-based learning in dental education: a systematic review of the literature. Journal of Dental Education, 78(1), 98-109.

Dharma, I. L. V. V., Suardana, I. N., \& Selamet, K. (2019). Pengaruh Model Problem-based Learning terhadap Keterampilan Berpikir Kritis Siswa Kelas VII SMP pada Pembelajaran IPA. Jurnal Pendidikan dan Pembelajaran Sains Indonesia (JPPSI), 1(1), 44-54.

Duda, H. J., Susilo, H., \& Newcombe, P. (2019). Enhancing different ethnicity science process skills: Problem-based learning through practicum and authentic assessment. International Journal of Instruction, 12(1), 1207-1222.

Fatimah, F. (2012). Kemampuan Komunikasi Matematis dalam Pembelajaran Statistika Elementer melalui Problem Based-Learning. Jurnal Cakrawala Pendidikan, 5(2).

Ferreira, M. M., \& Trudel, A. R. (2012). The impact of problem-based learning (PBL) on student attitudes toward science, problem-solving skills, and sense of community in the classroom. Journal of Classroom Interaction, 23-30.

Fristadi, R., \& Bharata, H. (2015). Meningkatkan Kemampuan Berpikir Kritis Siswa Dengan Problem Based Learning. Seminar Nasional Matematika dan Pendidikan UNY, 597-602.

Gunantara, G., Suarjana, I. M., \& Riastini, P. N. (2014). Penerapan model pembelajaran problem based learning untuk meningkatkan kemampuan pemecahan masalah matematika siswa 
kelas V. Mimbar PGSD Undiksha, 2(1).

Halarnkar, P., Shah, S., Shah, H., Shah, H., \& Shah, A. (2012). A review on virtual reality. International Journal of Computer Science Issues (IJCSI), 9(6), 325.

Indah, N., Mania, S., \& Nursalam, N. (2016). Peningkatan kemampuan literasi matematika siswa melalui penerapan model pembelajaran problem based learning di kelas VII SMP Negeri 5 Pallangga Kabupaten Gowa. MaPan: Jurnal Matematika dan Pembelajaran, 4(2), 200-210.

Insyasiska, D., Zubaidah, S., \& Susilo, H. (2017). Pengaruh project based learning terhadap motivasi belajar, kreativitas, kemampuan berpikir kritis, dan kemampuan kognitif siswa pada pembelajaran biologi. Jurnal Pendidikan Biologi, 7(1), 9-21.

Kharida, L. A., Rusilowati, A., \& Pratiknyo, K. (2009). Penerapan model pembelajaran berbasis masalah untuk peningkatan hasil belajar siswa pada pokok bahasan elastisitas bahan. Jurnal Pendidikan Fisika Indonesia, 5(2).

Lou, S.J., Shih, R.C., Diez, C. R., \& Tseng, K.H. (2011). The impact of problem-based learning strategies on STEM knowledge integration and attitudes: an exploratory study among female Taiwanese senior high school students. International Journal of Technology and Design Education, 21(2), 195-215.

Mansur, D. I., Kayastha, S. R., Makaju, R., \& Dongol, M. (2012). Problem based learning in medical education. Kathmandu University Medical Journal, 10(4), 78-82.

Nadershahi, N. A., Bender, D. J., Beck, L., Lyon, C., \& Blaseio, A. (2013). An overview of case-based and problem-based learning methodologies for dental education. Journal of Dental Education, 77(10), 1300-1305.

Nargundkar, S., Samaddar, S., \& Mukhopadhyay, S. (2014). A guided problem-based learning (PBL) approach: Impact on critical thinking. Decision Sciences Journal of Innovative Education, 12(2), 91-108.

Nicholl, T. A., \& Lou, K. (2012). A model for smallgroup problem-based learning in a large class facilitated by one instructor. American Journal of Pharmaceutical Education, 76(6).

Nurdyansyah, N. (2018). Model Pembelajaran Berbasis Masalah Pada Pelajaran IPA Materi Komponen Ekosistem. Universitas Muhammadiyah Sidoarjo.

Partini, N. N. A., Suweken, G., \& Suarsana, I. M. (2017). Pengaruh Model Pembelajaran Problem Based Learning Berbantuan PoWs terhadap Kemampuan Pemecahan Masalah Matematika Siswa Kelas VII SMP Negeri 4 Singaraja. Wahana Matematika dan Sains: Jurnal Matematika, Sains, dan Pembelajarannya, 9(2), 1-9.

Putri, N. D., Yunarti, T., \& Jalil, A. (2013). Efektivias Problem-Based Learning terhadap Kemampuan Pemecahan Masalah Matematis Siswa.
Jurnal Pendidikan Matematika Unila, 1(8).

Ramadhani, R., Umam, R., Abdurrahman, A., \& Syazali, M. (2019). The effect of flipped-problem based learning model integrated with LMS-google classroom for senior high school students. Journal for the Education of Gifted Young Scientists, 7(2), 137-158.

Saleh, M. (2013). Strategi Pembelajaran Fiqh dengan Problem-Based Learning. Jurnal Ilmiah Didaktika: Media Ilmiah Pendidikan dan Pengajaran, 14(1).

Saragih, S., \& Habeahan, W. L. (2014). The improving of problem solving ability and students' creativity mathematical by using problem based learning in SMP Negeri 2 Siantar. Journal of Education and Practice, 5(35), 123-133.

Setyorini, U., Sukiswo, S. E., \& Subali, B. (2011). Penerapan model problem based learning untuk meningkatkan kemampuan berpikir kritis siswa SMP. Jurnal Pendidikan Fisika Indonesia, $7(1)$.

Shankar, P. R. (2010). Problem-based learning: A Review. Journal of Clinical and Diagnostic Research, 4, 3249-3254.

Si, J., Kong, H.H., \& Lee, S.H. (2019). Developing clinical reasoning skills through argumentation with the concept map method in medical problem-based learning. Interdisciplinary Journal of Problem-Based Learning, 13(1).

Simbolon, E. R., \& Tapilouw, F. S. (2015). Pengaruh pembelajaran berbasis masalah dan pembelajaran kontekstual terhadap berpikir kritis siswa SMP. Edusains, 7(1), 97-104.

Sunarti, I., \& Fadilah, D. N. N. (2019). Penerapan Model Pembelajaran Problem Based Learning (PBL) terhadap Kemampuan Berpikir Kritis Siswa. Equilibrium: Jurnal Penelitian Pendidikan dan Ekonomi, 16(o1), 15-25.

Surya, E., Sabandar, J., Kusumah, Y. S., \& Darhim, D. (2013). Improving of junior high school visual thinking representation ability in mathematical problem solving by CTL. Journal on Mathematics Education, 4(1), 113-126.

Svanström, M., Gröndahl, F., Dobson, H. E., \& Tomkinson, C. B. (2012). Creating sustainable development change agents through problem-based learning. International Journal of Sustainability in Higher Education, 13, 263-278.

Trilling, B., \& Fadel, C. (2009). $21^{\text {st }}$ Century Skills: Learning for Life in Our Times. John Wiley \& Son, Inc.

Wartono, W., Diantoro, M., \& Bartlolona, J. R. (2018). Influence of problem based learning model on student creative thinking on elasticity topics a material. Jurnal Pendidikan Fisika Indonesia, 14(1), 32-39.

Zaduqisti, E. (2010). Problem-Based Learning (Konsep Ideal Model Pembelajaran untuk Peningkatan Prestasi Belajar dan Motivasi Berprestasi). Edukasia Islamika, 8(2), 181-191. 